\title{
Carcass and meat quality of Boer and indigenous goats of South Africa under delayed chilling conditions
}

\author{
P. Pophiwa ${ }^{1 \#}$, E.C. Webb ${ }^{1}$ \& L. Frylinck ${ }^{2}$ \\ ${ }^{1}$ Department of Animal \& Wildlife Sciences, University of Pretoria, Private bag X20, Hatfield 0028, South Africa. \\ ${ }^{2}$ Animal Production Institute, Agricultural Research Council of South Africa, Private bag X2, Irene 0062, South Africa.
}

(Received 1 September 2016; Accepted 4 August 2017; First published online 28 September 2017)

Copyright resides with the authors in terms of the Creative Commons Attribution 4.0 South African License.

See: http://creativecommons.org/licenses/by/4.0/za

Condition of use: The user may copy, distribute, transmit and adapt the work, but must recognize the authors and the South African Journal of Animal Science.

\begin{abstract}
This study was conducted to evaluate the carcass and meat quality of Boer goats and unimproved indigenous goats of South Africa, under delayed chilling conditions. Ten goats per breed were used for the study. The goats were slaughtered according to standard abattoir procedures. The dressed carcasses were held at $10-15{ }^{\circ} \mathrm{C}$ for 6 hours before chilling at $4{ }^{\circ} \mathrm{C}$ until 24 hours (delayed chilling). The $\mathrm{pH} /$ temperature values, instrumental colour (CIE $\mathrm{L}^{*}, \mathrm{a}^{*}, \mathrm{~b}^{*}$, chroma and hue angle), surface myoglobin pigments (deoxyglobin, oxyglobin and metmyoglobin), water-holding capacity (WHC), thawing loss, cooking loss, sarcomere length, and Warner Bratzler shear force (WBSF) values were evaluated on samples of the $m$. longissimus dorsi (LD) and the $m$. semimembranosus (SM). Carcasses of Boer goats were heavier and had higher chilling loss than those of indigenous goats. There were no breed differences in dressing percentages, $\mathrm{pH} /$ temperature values or meat quality characteristics. Overall, the mean ultimate $\mathrm{pH}$ values (5.75-5.80), were marginally higher than the recommended $\mathrm{pH}$ for desirable eating quality. However, the mean $L^{*}$ (36.3-40.2), $a^{*}(18.0-18.8)$, WHC (0.35-0.39) and metmyoglobin (16.3-18.8\%) values were within the range that is acceptable for normal meat. On average, LD samples were tender (WBSF values of $4.43 \pm$ $0.40 \mathrm{~kg}$ ), but SM samples were marginally tough (WBSF values of $8.45 \pm 0.54 \mathrm{~kg}$ ). This study shows that delayed chilling could be a useful strategy in improving the colour and tenderness of goat meat.
\end{abstract}

Keywords: Goat meat quality, meat colour, sarcomere length, tenderness

\#Corresponding author: Pamela.Pophiwa@tuks.co.za

\section{Introduction}

Goat meat (chevon) is salubrious and conforms to the current consumer demand for lean and nutritious meat (Kannan et al., 2014). However, the preference for goat meat in South Africa is relatively low owing to traditional misconceptions of off-odours, off-flavours, unappealing colour, and toughness. It should therefore be a priority to address quality concerns about goat meat, particularly attributes such as colour and tenderness as they determine the acceptability of the product.

The toughness of goat meat because of cold shortening of rapidly chilled carcasses is a known problem in the chevon industry worldwide (Kannan et al., 2014). Although delayed chilling of carcasses is a simpler and cheaper technique of counteracting the effects of cold shortening, its application in goats is not documented. Considering that there are emerging markets for goat meat in South Africa, research should focus on such techniques to improve the quality of goat meat.

The chevon industry of South Africa is dominated by Boer and indigenous goat breeds. The Boer goat is an improved breed that was developed for rapid growth and superior meat production traits (Malan, 2000). The so-called indigenous goats of South Africa are unimproved local varieties. These varieties are not defined, but are usually associated with the geographical area in which they are found, and are mostly valued for their hardiness (Visser et al., 2004).

Based on earlier research, particularly in pigs, in which selection for rapid growth and muscularity was studied extensively (McPhee \& Trout, 1995), it is possible that the commercial goat breeds of South Africa have divergent carcass and meat quality attributes. However, published information on the carcass and meat quality of Boer and indigenous goats is limited and fragmented (Van Niekerk \& Casey, 1988; Simela et al., 2004). Therefore, more studies are needed to evaluate the carcass and meat quality of South African goat meat breeds using the recommended slaughter technologies. This information gives a good indication of the quality of goat meat marketed in South Africa and provides a basis from which to improve product quality. 
The aim of this study was therefore to evaluate the carcass and meat quality of Boer and unimproved indigenous goats of South Africa under delayed chilling conditions.

\section{Materials and methods}

This project was approved by the Animal Ethics Committee of the University of Pretoria (ref no. EC072-13). A flock of newly weaned male kids (weighing between $14 \mathrm{~kg}$ and $20 \mathrm{~kg}$ ) from established populations of Boer and South African indigenous goat breeds was purchased from a group of farmers in Bronkhorstspruit, Gauteng, South Africa. The goats were transported over $57 \mathrm{~km}$ to Hatfield Experimental Farm of the University of Pretoria, Gauteng, South Africa. The goats were kept on a commercial diet of Meadow game pellets $(110 \mathrm{~g} / \mathrm{kg}$ dry matter (DM) crude protein, 3.68\% non-protein nitrogen, $25 \mathrm{~g} / \mathrm{kg} \mathrm{DM}$ crude fat, $110 \mathrm{~g} / \mathrm{kg}$ DM crude fibre, $6 \mathrm{~g} / \mathrm{kg}$ DM calcium and $2.5 \mathrm{~g} / \mathrm{kg}$ DM phosphorus). The commercial diet was provided at 3 per cent live weight per animal per day to meet their nutritional requirements. Lucerne hay and clean water were available ad libitum. After adaptation, the kids were castrated using Burdizzo clamps. The goats were reared for approximately 200 days to attain a marketable weight of between $30 \mathrm{~kg}$ and 40 $\mathrm{kg}$.

Ten goats per breed (A-age class, weighing between $30 \mathrm{~kg}$ and $40 \mathrm{~kg}$ ) were randomly selected for slaughter. A day prior to slaughter, the goats were weighed and transported over $26 \mathrm{~km}$ to the abattoir of the Agricultural Research Council, Irene, Gauteng, South Africa. The goats were kept in lairage overnight with free access to feed and water to minimize ante mortem stress, which may occur because of feed withdrawal. The goats were slaughtered and dressed according to standard procedures at the abattoir. Carcasses of both the Boer and indigenous goats were held at $10-15^{\circ} \mathrm{C}$ for 6 hours before chilling at $4{ }^{\circ} \mathrm{C}$ until 24 hours (delayed chilling). Muscle $\mathrm{pH}$ and temperature readings were taken between the fourth and fifth lumbar vertebra and close to the posterior end of the m. semimembranosus (SM) at 30 minutes, 1 hour, 3 hours, 6 hours, and 24 hours post mortem. The readings were taken by inserting a portable pH meter (Eutech Instruments, CyberScan) ( $\mathrm{pH} \mathrm{11)} \mathrm{into} \mathrm{the} \mathrm{muscle} \mathrm{to} \mathrm{a} \mathrm{depth} \mathrm{of} \mathrm{about} 1.5 \mathrm{~cm}$. Dressing percentages and chilling loss were calculated as follows:

Dressing percentage $=\frac{\text { cold carcass weight }}{\text { live weight }} \times 100$

Chilling loss $(\%)=\frac{\text { hot carcass weight }- \text { cold carcass weight }}{\text { hot carcass weight }} \times 100$

The $m$. longissimus dorsi (LD) and SM were dissected from the carcasses of the Boer and indigenous goats. Fresh meat samples, weighing approximately $50 \mathrm{~g}$, were kept at $4{ }^{\circ} \mathrm{C}$ to determine sarcomere length, water holding capacity, instrumental colour values, and surface myoglobin pigments. Meat samples of approximately $200 \mathrm{~g}$ were vacuum packed and kept frozen at $-20^{\circ} \mathrm{C}$ to determine thawing loss, cooking loss, and Warner Bratzler shear force (WBSF) values.

Fresh meat samples of $15 \mathrm{~mm}$ thickness were allowed to bloom for 1 hour at $0-4{ }^{\circ} \mathrm{C}$ before the colour values were read. A Konica-Minolta 600d spectrophotometer with the Spectra Magic NX Pro software package was used to read instrumental colour values (CIE lightness $\left(L^{*}\right)$, redness $\left(a^{*}\right)$, yellowness $\left(b^{*}\right)$, chroma and hue angle). The spectrometer configuration consisted of illuminant D65, observer angle $10^{\circ}$, and measurement aperture $8 \mathrm{~mm}$. Measurements were taken with the spectral component excluded after calibration using the included white reference. Three readings were taken from each sample and the mean values were used for statistical analyses. Spectral reflectance values were measured in the visible wavelength between $360 \mathrm{~nm}$ and $740 \mathrm{~nm}$ at $10 \mathrm{~nm}$ intervals. Surface myoglobin pigments, namely deoxymyoglobin, oxymyoglobin, and metmyoglobin, were calculated according to Krzywicki (1979) using the reflex attenuation $\log \left(\frac{1}{R}\right)$ at isobestic points $474 \mathrm{~nm}, 525 \mathrm{~nm}$ and $572 \mathrm{~nm}$ (calculated by linear interpolation) and $730 \mathrm{~nm}$.

Water holding capacity was determined with the filter paper press method described by Strydom et al. (2005). The borders of meat and fluid expressed were marked out and their areas were measured with a video image analyser (Soft Imaging System, Olympus, Japan), according to Irie et al. (1996). Water holding capacity was expressed as a ratio of meat area to fluid area.

Meat samples for sarcomere lengths were prepared according to Hegarty \& Naudé (1970) using distilled water (Dreyer et al., 1979). A few drops of the homogenate were placed on a slide and covered with a cover slip. The slides were viewed under an Olympus B340 microscope system attached to a CC12 video camera (Olympus, Tokyo, Japan). An Analysis Life Sciences software package was used to analyse the data. Fifty sarcomeres were measured per sample, and the mean length was used for statistical analysis. 
Frozen meat samples were thawed at $0-4{ }^{\circ} \mathrm{C}$ for 24 hours. The thawed samples were broiled in an oven (Miele $\mathrm{H}$ 217) pre-set at $190^{\circ} \mathrm{C}$, to an internal temperature of $70^{\circ} \mathrm{C}$. Thawing loss was expressed as a percentage of pre-thawed weight, and cooking loss was expressed as a percentage of pre-cooked weight. The cooked meat samples were cooled to an internal temperature of $19{ }^{\circ} \mathrm{C}$. Six cores with a diameter of 12.5 $\mathrm{mm}$ were removed parallel to the direction of muscle fibres from each cooked sample. The cores were sheared with a Warner Bratzler shear device mounted on a Universal Instron apparatus (Model 4301, Instron Ltd, Buckinghamshire, UK, crosshead speed $200 \mathrm{~mm} / \mathrm{min}$, one shear in the centre of each core). The toughness of meat was measured as the average peak force $(\mathrm{kg})$ required to shear through the six cores per meat sample.

The data were analysed using the general linear model procedure in IBM SPSS Statistics version 23.0. The effect of breed on live weight, hot and cold carcass weight, dressing percentage, chilling loss, $\mathrm{pH}$ and temperature, instrumental colour values $\left(L^{*}, a^{*}, b^{*}\right)$, chroma and hue angle), myoglobin pigments (deoxymyoglobin, oxymyoglobin and metmyoglobin), sarcomere length, cooking loss, thawing loss and WBSF were analysed using multivariate analysis of variance. Muscle $\mathrm{pH} /$ temperature values were analysed as repeated measurements. Means were compared using the least significant difference procedure and differences were considered significant at $P<0.05$. Pearson's correlation coefficients were calculated to determine the relationships between meat quality parameters.

\section{Results and discussion} Table 1.

Mean values for live weight and carcass characteristics of Boer and indigenous goats are presented in

Table 1 Mean values for live weight $(\mathrm{kg})$ and selected carcass characteristics of Boer and South African indigenous goats

\begin{tabular}{|c|c|c|c|c|}
\hline \multirow{2}{*}{ Characteristic } & \multicolumn{2}{|c|}{ Breed $(n=10$ goats per breed) } & \multirow{2}{*}{ Pooled SEM } & \multirow{2}{*}{ Significance $^{\dagger}$} \\
\hline & Boer goats & Indigenous goats & & \\
\hline Live weight (kg) & 39.8 & 33.7 & 0.79 & $\star \star \star *$ \\
\hline Hot carcass weight $(\mathrm{kg})$ & 19.9 & 16.7 & 0.43 & $\star \star \star *$ \\
\hline Cold carcass weight (kg) & 18.9 & 16.0 & 0.41 & $\star \star \star *$ \\
\hline Dressing percentage & 47.5 & 47.5 & 0.56 & NS \\
\hline Chilling loss (\%) & 4.81 & 4.03 & 0.16 & ** \\
\hline
\end{tabular}

${ }^{\dagger}$ NS: not significant; ${ }^{* *}(P<0.01) ;{ }^{* \star *}(P<0.001)$

The average live weight at slaughter for the Boer and indigenous goats compares well with weights reported for yearling goats of various genotypes (Gadiyaram et al., 2008; Kouakou et al., 2005; Kadim et al., 2006). Boer goats were $6.1 \mathrm{~kg}$ heavier $(P<0.001)$ than those of indigenous goats and their chilled carcasses were $2.9 \mathrm{~kg}$ heavier $(P<0.001)$. The breed differences in live weight and carcass weight are attributed to the fact that Boer goats have more rapid growth and superior meat production traits. Hence, they outgrow indigenous goats. Although indigenous goats tend to be smaller than Boer goats, most indigenous goats of Southern Africa are large framed and have high potential for meat production (Simela et al., 1999). In the present study, both Boer and indigenous goats attained a marketable weight of between $30 \mathrm{~kg}$ and $40 \mathrm{~kg}$ in their first year (before eruption of permanent teeth). According to the current South African carcass classification system, animals with no permanent incisors are designated A-age class and have better ratings than those with a higher number of permanent teeth. Farmers therefore do not need to keep such large goats beyond their second year, as the quality of meat deteriorates with age.

Dressing percentage is defined as the proportion of live weight that is converted into carcass (Warmington \& Kirton, 1990). Knowledge of the dressing percentage can assist farmers to achieve target carcass weights before goats are slaughtered. In the present study, the mean dressing percentage of $47.5 \%$ for both Boer and indigenous goats compares well with values reported for goats (Hogg et al., 1992; Marichal et al., 2003; Safari et al., 2011). Consistent with the results of Tshabalala et al. (2003), dressing percentage did not differ significantly between the goat breeds. According to Warmington \& Kirton (1990), goats are generally lean. Consequently, there is little breed difference in their dressing percentage. Studies that 
reported breed differences in dressing percentages of goats attributed these variations to factors such as age, degree of gut fill at slaughter, and dressing procedure (Dhanda et al., 1999; Kadim et al., 2003; Gökdal, 2013).

Chilling loss was higher $(P<0.01)$ in carcasses of Boer goats than in those of indigenous goats, possibly because of variations in carcass weight. Similarly, Kadim et al. (2006), in their study with three Omani goat breeds, reported that the Jabal Akhdar goat breed had higher carcass weight and hence higher chilling loss (shrinkage) compared with the Dhofari and Jabal Akhdar breeds. Overall, the chilling loss for this study was marginally higher than $3 \%$, which is usually estimated for goat carcasses (Webb et al., 2005, Simela et al., 2011).

Mean $\mathrm{pH}$ and temperature values at 30 min and 1, 3, 6 and 24 hours post mortem for goat LD and SM are shown in Tables 2 and 3, respectively.

Table 2 Mean $\mathrm{pH}$ and temperature values at $30 \mathrm{~min}, 1,3,6$, and $24 \mathrm{~h}$ post mortem for the $\mathrm{m}$. longissimus dorsi of Boer and South African indigenous goats

\begin{tabular}{lccccc}
\hline \multirow{2}{*}{ Parameter } & Time post mortem & \multicolumn{2}{c}{ Breed $(\mathbf{n}=\mathbf{1 0}$ goats per breed $)$} & \multirow{2}{*}{ Pooled SEM } & \multirow{2}{*}{ Significance $^{\dagger}$} \\
\cline { 3 - 4 } & & Boer goats & Indigenous goats & & \\
& $30 \mathrm{~min}$ & 6.53 & 6.54 & 0.08 & $\mathrm{NS}$ \\
$\mathrm{nH}$ & $1 \mathrm{~h}$ & 6.40 & 6.45 & 0.09 & $\mathrm{NS}$ \\
& $3 \mathrm{~h}$ & 6.25 & 6.40 & 0.10 & $\mathrm{NS}$ \\
& $6 \mathrm{~h}$ & 6.09 & 6.18 & 0.12 & $\mathrm{NS}$ \\
& $24 \mathrm{~h}$ & 5.76 & 5.76 & 0.05 & $\mathrm{NS}$ \\
& $30 \mathrm{~min}$ & 37.9 & 37.9 & 0.50 & $\mathrm{NS}$ \\
Temperature $\left({ }^{\circ} \mathrm{C}\right)$ & $1 \mathrm{~h}$ & 29.1 & 28.1 & 1.11 & $\mathrm{NS}$ \\
& $3 \mathrm{~h}$ & 17.8 & 18.3 & 0.98 & $\mathrm{NS}$ \\
& $6 \mathrm{~h}$ & 14.4 & 14.9 & 0.38 & $\mathrm{NS}$ \\
& $24 \mathrm{~h}$ & 4.71 & 4.30 & 0.25 & $\mathrm{NS}$ \\
\hline
\end{tabular}

${ }^{\dagger}$ NS: not significant

Rate and extent of $\mathrm{pH}$ decline are known to affect the development of key meat quality attributes such as colour and tenderness (Simela et al., 2004). In this study, muscle pH gradually dropped from $\sim 6.6$ to $\sim 5.8$. The average ultimate $\mathrm{pH}$ value for LD and SM corresponded to reported values for muscles of various goat breeds (Dhanda et al., 2003; Kadim et al., 2003; Simela et al., 2004). However, these average ultimate pH values were marginally higher than the recommended $\mathrm{pH}$ (5.5) for desirable eating quality (Tarrant \& Sherington, 1980). High ultimate $\mathrm{pH}$ is indicative of ante mortem stress, and could result in low quality meat. Simela et al. (2004) reported a tendency towards the dark firm and dry (DFD) condition for chevon with an ultimate $\mathrm{pH}$ higher than 6 . In bovine animals, muscles with a $\mathrm{pH}$ higher than 5.8 are usually classified as DFD (Tarrant \& Sherington, 1980).

A classic study by Locker \& Hagyard (1963) showed that the combination of $\mathrm{pH}$ and temperature prior to the onset of rigor mortis is crucial for improved meat tenderness. Ideally, $\mathrm{pH}$ should drop to 6 , while carcass temperature is between $14^{\circ} \mathrm{C}$ and $19{ }^{\circ} \mathrm{C}$. Temperatures below $10^{\circ} \mathrm{C}$ or above $35^{\circ} \mathrm{C}$ at the onset of rigor mortis $(\mathrm{pH} \sim 6)$ can cause excessive sarcomere shortening, thus affecting meat tenderness. Decreased goat meat tenderness is usually ascribed to excessive sarcomere shortening during normal commercial chilling conditions $\left( \pm 4^{\circ} \mathrm{C}\right.$ for 24 hours). For example, sarcomeres shorter than $1.6 \mu \mathrm{m}$ have been reported in conventionally chilled goat carcasses (Kadim et al., 2014). Goat carcasses are generally small and have a thin subcutaneous fat layer, which permits rapid dissipation of heat, leading to cold shortening and subsequent muscle toughening. Control of the post-mortem $\mathrm{pH} /$ temperature combination is therefore crucial in achieving goat meat of better quality. In this study, the authors opted for delayed chilling of carcasses to ensure that muscles entered rigor mortis at temperatures above $10^{\circ} \mathrm{C}$. The average muscle $\mathrm{pH}$ dropped to or was close to 6 , while temperature values were between $13.1^{\circ} \mathrm{C}$ and $17.1^{\circ} \mathrm{C}$ at 6 hours post mortem. This shows that delayed chilling was effective in slowing down the rate of carcass temperature decline, a process that would minimise the risk of cold shortening. In fact, all the sarcomeres measured were longer than $2 \mu \mathrm{m}$, 
an indication that cold shortening did not occur in the slaughter conditions set for this study (Biswas et al., 2007).

Table 3 Mean $\mathrm{pH}$ and temperature values at $30 \mathrm{~min}, 1,3,6$, and $24 \mathrm{~h}$ post mortem for the $\mathrm{m}$. semimembranosus muscles of Boer and South African indigenous goats

\begin{tabular}{lccccc}
\hline \multirow{2}{*}{ Parameter } & Time post mortem & \multicolumn{2}{c}{ Breed $(\mathbf{n}=\mathbf{1 0}$ goats per breed $)$} & \multirow{2}{*}{ Pooled SEM } & Significance $^{\dagger}$ \\
\cline { 3 - 4 } & & Boer goats & Indigenous goats & & \\
\hline \multirow{2}{*}{$\mathrm{pH}$} & $30 \mathrm{~min}$ & 6.56 & 6.58 & 0.09 & NS \\
& $1 \mathrm{~h}$ & 6.47 & 6.39 & 0.07 & $\mathrm{NS}$ \\
& $3 \mathrm{~h}$ & 6.26 & 6.28 & 0.09 & $\mathrm{NS}$ \\
& $6 \mathrm{~h}$ & 6.05 & 6.14 & 0.09 & $\mathrm{NS}$ \\
Temperature $\left({ }^{\circ} \mathrm{C}\right)$ & $24 \mathrm{~h}$ & 5.80 & 5.75 & 0.06 & $\mathrm{NS}$ \\
& $30 \mathrm{~min}$ & 38.1 & 38.6 & 0.61 & $\mathrm{NS}$ \\
& $1 \mathrm{~h}$ & 31.6 & 30.6 & 1.32 & $\mathrm{NS}$ \\
& $3 \mathrm{~h}$ & 19.5 & 19.4 & 0.63 & $\mathrm{NS}$ \\
& $6 \mathrm{~h}$ & 14.8 & 14.7 & 0.40 & $\mathrm{NS}$ \\
& $24 \mathrm{~h}$ & 4.19 & 4.62 & 0.30 & $\mathrm{NS}$ \\
\hline
\end{tabular}

${ }^{\dagger} \mathrm{NS}$ : not significant

Meat quality attributes for goat LD and SM, as influenced by breed, are presented in Tables 4 and 5 , respectively.

Table 4 Mean values for objective meat quality characteristics of the $m$. longissimus dorsi of Boer and indigenous goats

\begin{tabular}{|c|c|c|c|c|}
\hline \multirow{2}{*}{ Parameter } & \multicolumn{2}{|c|}{ Breed ( $n=10$ goats per breed ) } & \multirow{2}{*}{ Pooled SEM } & \multirow{2}{*}{ Significance $^{\dagger}$} \\
\hline & Boer goats & Indigenous goats & & \\
\hline$L^{*}$ & 39.9 & 40.2 & 1.07 & NS \\
\hline$a^{*}$ & 18.0 & 18.3 & 0.72 & NS \\
\hline$b^{*}$ & 12.6 & 12.4 & 0.50 & NS \\
\hline Chroma & 22.0 & 22.1 & 0.85 & NS \\
\hline Hue angle & 35.0 & 34.2 & 0.56 & NS \\
\hline Deoxymyoglobin (\%) & 56.5 & 57.2 & 3.37 & NS \\
\hline Oxymyoglobin (\%) & 27.1 & 25.9 & 2.53 & NS \\
\hline Metmyoglobin (\%) & 16.3 & 16.9 & 0.97 & NS \\
\hline Index for water holding capacity & 0.38 & 0.39 & 0.02 & NS \\
\hline Thawing loss (\%) & 2.37 & 2.46 & 0.66 & NS \\
\hline Cooking loss (\%) & 18.9 & 17.5 & 1.30 & NS \\
\hline Sarcomere length $(\mu \mathrm{m})$ & 2.10 & 2.09 & 0.05 & NS \\
\hline Warner Bratzler shear force $(\mathrm{kg})$ & 4.33 & 4.53 & 0.40 & NS \\
\hline
\end{tabular}


Table 5 Mean values for objective meat quality characteristics of the $m$. semimembranosus muscle of Boer and indigenous goats

\begin{tabular}{|c|c|c|c|c|}
\hline \multirow{2}{*}{ Parameter } & \multicolumn{2}{|c|}{ Breed $(n=10$ goats per breed $)$} & \multirow{2}{*}{ Pooled SEM } & \multirow{2}{*}{ Significance } \\
\hline & Boer goats & Indigenous goats & & \\
\hline$L^{*}$ & 36.3 & 36.3 & 0.99 & NS \\
\hline$a^{*}$ & 18.8 & 18.6 & 0.63 & NS \\
\hline$b^{*}$ & 12.3 & 11.8 & 0.49 & NS \\
\hline Chroma & 22.5 & 21.9 & 0.76 & NS \\
\hline Hue angle & 33.2 & 32.4 & 0.65 & NS \\
\hline Deoxymyoglobin (\%) & 58.1 & 59.7 & 3.38 & NS \\
\hline Oxymyoglobin (\%) & 23.6 & 21.6 & 2.47 & NS \\
\hline Metmyoglobin (\%) & 18.3 & 18.8 & 0.89 & NS \\
\hline Index for water holding capacity & 0.35 & 0.35 & 0.02 & NS \\
\hline Thawing loss (\%) & 5.96 & 6.05 & 0.69 & NS \\
\hline Cooking loss (\%) & 24.7 & 25.7 & 1.92 & NS \\
\hline Sarcomere length $(\mu \mathrm{m})$ & 2.12 & 2.01 & 0.06 & NS \\
\hline Warner Bratzler shear force $(\mathrm{kg})$ & 8.06 & 8.84 & 0.54 & NS \\
\hline
\end{tabular}

${ }^{\dagger}$ NS: not significant; $L^{*}$ : lightness; $a^{*}$ : redness; $b^{*}$ : yellowness

Meat colour is an important characteristic that influences consumers' perceptions of the quality of the product. Bright red meat is the usual preference, and consumers often discriminate against meat that does not meet their expectations. The characteristic colour of goat meat has not been established, but there are perceptions that goat meat is darker than other types of red meat. Dark meat is typical of animals exposed to chronic ante-mortem stress (Kadim et al., 2006). In the present study, the average L* (lightness), $a^{*}$ (redness), $b^{*}$ (yellowness) values were in the range of 36.3-40.2, 18.0-18.8, and 11.8-12.6, respectively, with no significant differences between the goat breeds. These instrumental colour values compare well with reported values for muscles of various goat breeds (King et al., 2004; Simela et al., 2004; Kadim et al., 2006). The current results seem to agree with those of Gadiyaram et al. (2008), who reported non-significant breed differences in the colour of goat meat.

Three main chemical forms of myoglobin, namely deoxymyoglobin, oxymyoglobin and metmyoglobin, give fresh meat its characteristic colour (Cornforth, 1994). Accumulation of metmyoglobin is known to be the basis of meat discolouration. In this study, the average metmyoglobin fractions (16.3-18.8\%) were lower than the values reported by Kannan et al. (2001) for various muscles of Spanish goats (26.5-28.7\%). Since consumer rejection may occur at metmyoglobin levels as low as $20 \%$ (Hood \& Riordan, 1973), the goat meat samples evaluated in this study were not visibly discoloured at one day post mortem. However, ageing may have a negative influence on the colour of goat meat owing to myoglobin oxidation (Kannan et al., 2001). According to Kannan et al. (2014), goat meat is high in polyunsaturated fatty acids, which could make the meat more susceptible to lipid and myoglobin oxidation on exposure to oxygen.

Juiciness of meat is the moisture sensation of the cooked product, and is closely linked to water holding capacity, thawing loss and cooking loss (Schönfeldt et al., 1993). In the present study, the average values for water holding capacity, as indicated by the amount of juice expressed, ranged from 0.35 to 0.39 . A similar range for expressed juice was reported by Kadim et al. (2003) in their study with various muscles of the Batina, Dhofari and Jabal Akhdar goat breeds. Thawing is known to exacerbate water loss in meat. In the present study, thawing loss were in the range $2.23-6.05 \%$. Information about thawing loss of goat meat is limited, but Schönfeldt et al. (1993) reported thawing loss of less than $1 \%$ in $\mathrm{m}$. longissimus thoracis et lumborum and $\mathrm{m}$. semimembranosus of Angora and Boer goats. These authors aged their meat samples for seven days prior to freezing, which could have improved the water holding capacity

Generally, goat muscles have low intramuscular fat content. Hence they tend to have low drip loss and high evaporative loss during cooking, giving the impression of being of poor eating quality (Casey, 1992). In this study, the average cooking loss of LD and SM for the two breeds was in the range of $17.5-25.7 \%$, which is within the normal range for goat muscles (Schönfeldt et al., 1993; Kadim et al., 2006; Lee et al., 2008). Other authors have reported cooking loss of goat meat that was higher than 30\% (Kadim et al., 2003; 
Abdullah \& Musallam, 2007; Pratiwi et al., 2007). Differences in cooking loss found by these authors could be attributed to differences in time, temperature of cooking, ultimate $\mathrm{pH}$ and the type of muscle. Overall, there were no breed differences in water holding capacity, thawing loss, and cooking loss of goat meat. Other authors have also reported non-significant breed differences in water holding capacity (Kadim et al., 2003), thawing loss (Schönfeldt et al., 1993), and cooking loss (Madruga et al., 2008). These moisturerelated parameters are strongly influenced by the ultimate $\mathrm{pH}$ of meat (Gault, 1985). In this study, breed had no effect on muscle ultimate $\mathrm{pH}$, therefore it is possible that water holding capacity, thawing loss and cooking loss were not different between the breeds either.

Meat with a shear force value of less than $5.5 \mathrm{~kg}$ is considered tender by a trained sensory panel and consumers (Shackelford et al., 1991). In this study, LD had an acceptable degree of tenderness at one day post mortem (average WBSF $4.43 \pm 0.40 \mathrm{~kg}$. This finding may be ascribed partly to the content and solubility of collagen in the m. longissimus dorsi (Marichal et al., 2003). In contrast to the results of the current study, Kadim et al. (2014) reported shear force values in the range of $6.7-10 \mathrm{~kg}$ for the $\mathrm{m}$. longissimus dorsi of rapidly chilled goat carcasses. These workers attributed the increased meat toughness to excessive sarcomere shortening (sarcomeres of 1.4-1.6 $\mu \mathrm{m}$ ) under normal chilling conditions. In the present study, delayed chilling may have reduced the deleterious effects associated with cold shortening and subsequently have improved meat tenderness. Another possible explanation relating to the carcass treatment is that a combination of low $\mathrm{pH}$ and high temperature effected by delayed chilling stimulated proteolytic enzyme activity and improved meat tenderness (Hwang et al., 2004). One of a combination of these factors might explain the tenderness of LD samples that was observed in the present study.

The SM samples of both Boer and indigenous goats were marginally tough, with an average WBSF of $8.45 \pm 0.54 \mathrm{~kg}$. Although the WBSF values of SM samples were relatively high, they were similar to published values in other goat breeds (Kadim et al., 2003). The higher shear force values for the $m$. semimembranosus could be because of higher calpastatin activity, which are known to inhibit the action of calpains in mediating proteolysis (Nagaraj et al., 2002). Post-mortem ageing may be considered in order to improve the tenderness of goat meat. In this study, the effects of ageing on goat meat quality could not be investigated because the muscles were small and limited. There were no breed differences in WBSF values of the LD and SM, as reported by Johnson et al. (1995). Breed differences or lack of them in the tenderness of goat meat, depend on factors such as age, level of nutrition, time and temperature of cooking, ultimate $\mathrm{pH}$ and the type of muscle (Kadim et al., 2003).

Pearson correlations between meat quality parameters of goat LD and SM are presented in Table 6 and 7 , respectively.

Table 6 Pearson correlations for meat quality traits for the $m$. longissimus dorsi of Boer and indigenous goats (pooled data)

\begin{tabular}{|c|c|c|c|c|c|c|c|c|c|c|c|c|}
\hline & T2 & T3 & T4 & T5 & T6 & $\mathrm{T7}$ & T8 & T9 & T10 & T11 & T12 & T13 \\
\hline $\mathrm{T} 1 \mathrm{pH}_{24}$ & -0.22 & -0.26 & -0.23 & 0.20 & $0.58^{\star *}$ & $-0.63^{\star *}$ & -0.37 & $0.55^{\star}$ & 0.11 & -0.08 & $0.46^{*}$ & -0.14 \\
\hline $\mathrm{T} 2 \mathrm{~L}^{*}$ & & -0.41 & -0.33 & $0.52^{*}$ & -0.03 & 0.05 & -0.03 & -0.24 & -0.12 & -0.06 & -0.01 & $0.46^{*}$ \\
\hline T3 $a^{*}$ & & & $0.99^{* * *}$ & -0.23 & $-0.78^{\star * *}$ & $0.73^{\star * *}$ & $0.81^{\star * *}$ & -0.25 & -0.12 & -0.02 & 0.20 & -0.13 \\
\hline T4 chroma & & & & -0.06 & $-0.83^{\star \star \star}$ & $0.78^{\star \star \star}$ & $0.84^{\star \star \star}$ & -0.27 & -0.15 & 0.03 & 0.28 & -0.06 \\
\hline T5 hue angle & & & & & -0.16 & 0.19 & 0.05 & -0.10 & -0.17 & 0.30 & 0.43 & 0.41 \\
\hline T6 $\mathrm{DMB}^{1}$ & & & & & & $-0.98^{\star * *}$ & $-0.88^{\star * *}$ & $0.56^{\star \star}$ & 0.13 & -0.17 & -0.17 & -0.23 \\
\hline $\mathrm{T7} \mathrm{OMB}^{2}$ & & & & & & & $0.79^{\star * *}$ & $-0.63^{\star *}$ & -0.19 & 0.20 & 0.11 & 0.23 \\
\hline $\mathrm{T}_{8} \mathrm{MMB}^{3}$ & & & & & & & & -0.28 & 0.04 & 0.08 & 0.28 & 0.20 \\
\hline T9 $\mathrm{WHC}^{4}$ & & & & & & & & & 0.28 & 0.10 & 0.07 & -0.09 \\
\hline T10 Thawing loss & & & & & & & & & & 0.25 & -0.10 & 0.05 \\
\hline T11 Cooking loss & & & & & & & & & & & -0.06 & 0.10 \\
\hline T12 Sarcomere length & & & & & & & & & & & & 0.04 \\
\hline T13 WBSF ${ }^{5}$ & & & & & & & & & & & & 1 \\
\hline
\end{tabular}

'deoxymyoglobin; ${ }^{1}$ oxymyoglobin; ${ }^{3}$ metmyoglobin; ${ }^{4}$ water-holding capacity; ${ }^{5}$ Warner Bratzler shear force 
Muscle ultimate $\mathrm{pH}$ is known to influence meat quality characteristics such as colour, water holding capacity and tenderness (Lawrie \& Ledward, 2006). In this study, the ultimate pH of LD samples was inversely correlated to oxymyoglobin and positively correlated to both deoxymyoglobin and water holding capacity. The ultimate $\mathrm{pH}$ of $\mathrm{SM}$ samples was inversely correlated to the $\mathrm{L}^{*}$ value. Although the average ultimate $\mathrm{pH}$ values did not deviate much from the normal values, there were individual samples with $\mathrm{pH}$ values higher than 6 . According to the correlations obtained in this study, this elevated $\mathrm{pH}$ would lead to dark meat with a high water holding capacity. The current results on correlations between meat quality characteristics support the notion that high muscle ultimate $\mathrm{pH}$ promotes conditions that limit the formation of oxymyoglobin formation, resulting in dark meat (Kadim et al., 2006).

Table 7 Pearson correlations for meat quality traits of the $\mathrm{m}$. semimembranosus of Boer and indigenous goats (pooled data)

\begin{tabular}{|c|c|c|c|c|c|c|c|c|c|c|c|c|}
\hline & T2 & T3 & T4 & T5 & T6 & T7 & T8 & T9 & T10 & T11 & $\mathrm{T} 12$ & T13 \\
\hline $\mathrm{T} 1 \mathrm{pH}_{24}$ & $-0.51^{*}$ & -0.37 & -0.35 & 0.08 & 0.30 & -0.25 & -0.39 & 0.42 & 0.43 & -0.08 & 0.41 & -0.30 \\
\hline $\mathrm{T} 2 \mathrm{~L}^{*}$ & & 0.19 & 0.30 & $0.48^{*}$ & -0.30 & 0.32 & 0.20 & -0.29 & $-0.46^{*}$ & 0.07 & -0.12 & -0.06 \\
\hline T3 $a^{*}$ & & & $0.98^{* * *}$ & -0.06 & $-0.78^{\star \star \star}$ & $0.76^{\star \star \star}$ & $0.76^{\star \star \star}$ & -0.34 & -0.24 & -0.08 & 0.22 & $0.49^{*}$ \\
\hline T4 Chroma & & & & 0.15 & $-0.82^{* * *}$ & $0.82^{\star * \star}$ & $0.74^{\star \star \star}$ & -0.33 & -0.25 & -0.02 & 0.26 & 0.41 \\
\hline T5 Hue angle & & & & & -0.22 & 0.32 & -0.08 & 0.08 & -0.02 & 0.25 & 0.22 & -0.34 \\
\hline T6 $\mathrm{DMB}^{1}$ & & & & & & $-0.99^{* \star *}$ & $-0.91^{* * *}$ & $0.50^{*}$ & 0.16 & -0.00 & -0.02 & -0.22 \\
\hline $\mathrm{T} 7 \mathrm{OMB}^{2}$ & & & & & & & $0.85^{\star \star \star}$ & $-0.49^{*}$ & -0.13 & 0.00 & 0.09 & 0.17 \\
\hline $\mathrm{T}_{8} \mathrm{MMB}^{3}$ & & & & & & & & $-0.48^{*}$ & -0.23 & 0.01 & -0.18 & 0.34 \\
\hline T9 $\mathrm{WHC}^{4}$ & & & & & & & & & -0.00 & -0.02 & 0.35 & 0.11 \\
\hline T10 Thawing loss & & & & & & & & & & -0.41 & 0.18 & -0.29 \\
\hline T11 Cooking loss & & & & & & & & & & & 0.03 & 0.17 \\
\hline T12 Sarcomere length & & & & & & & & & & & & 0.09 \\
\hline T13 WBSF ${ }^{5}$ & & & & & & & & & & & & 1 \\
\hline
\end{tabular}

${ }^{1}$ deoxymyoglobin; ${ }^{2}$ oxymyoglobin; ${ }^{3}$ metmyoglobin; ${ }^{4}$ water-holding capacity; ${ }^{5}$ Warner Bratzler shear force

\section{Conclusion}

Breed was not a main factor pertaining to the development of quality attributes such as colour, tenderness and juiciness of goat meat. This study has shown that there is potential to market goat meat as a product of acceptable eating quality, if proper slaughter procedures are practised.

\section{Acknowledgements}

The authors would like to thank Agricultural Research Council, Meat Science Department, Irene, South Africa, for research facilities and technical assistance. The National Research Foundation (NRF, SF88758) is acknowledged for financial assistance.

\section{Authors' contributions}

PP collected the data and drafted the manuscript. ECW designed the study, analysed the data and revised the manuscript. LF assisted in data collection and revised the manuscript. All authors approved the final manuscript.

\section{Conflict of interest declaration}

The authors have no financial, personal or other relationships with other people or organisations work that could inappropriately influence, or perceived to influence their work.

\section{References}

Abdullah, A.Y. \& Musallam, H.S., 2007. Effect of different levels of energy on carcass composition and meat quality of male black goat kids. Livest. Sci. 107, 70-80.

Biswas, S.D., Das, A.K., Banerjee, R. \& Sharma, N., 2007. Effect of electrical stimulation on quality of tenderstretched chevon sides. Meat Sci. 75, 332-336.

Casey, N.H., 1992. Goat meat in human nutrition. Proc. 5th Int. Goats Conf. New Delhi, India. 
Cornforth, D., 1994. Color-Its basis and importance. In: Quality attributes and their measurement in meat, poultry and fish products. A.M. Pearson \& T.R. Dutson (eds). Chapman \& Hall, London. pp 34-78.

Dhanda, J.S., Taylor, D.G., McCosker, J.E. \& Murray, P.J., 1999. The influence of goat genotype on the production of capretto and chevon carcasses. 1. Growth and carcass characteristics. Meat Sci. 52, 355-361.

Dhanda, J.S., Taylor, D.G. \& Murray, P.J., 2003. Part 1. Growth, carcass and meat quality parameters of male goats: Effects of genotype and live weight at slaughter. Small Rumin. Res. 50, 57-66.

Dreyer, J.H., Van Rensburg, A.J.J., Naudé, R.T., Gouws, P.J. \& Stiemie, S., 1979. The effect of chilling temperatures and mode of suspension of beef carcasses on sarcomere length and meat tenderness. S. Afr. J. Anim. Sci. 9, 1-9.

Gadiyaram, K.M., Kannan, G., Pringle, T.D., Kouakou, B., McMillin, K.W. \& Park, Y.W., 2008. Effects of postmortem carcass electrical stimulation on goat meat quality characteristics. Small Rumin. Res. 78, 106-114.

Gault, N.F.S., 1985. The relationship between water-holding capacity and cooked meat tenderness in some beef muscles as influenced by acidic conditions below the ultimate $\mathrm{pH}$. Meat Sci. 15, 15-30.

Gökdal, Ö., 2013. Growth, slaughter and carcass characteristics of Alpine $\times$ Hair goat, Saanen $\times$ Hair goat and Hair goat male kids fed with concentrate in addition to grazing on rangeland. Small Rumin. Res. 109, 69-75.

Hegarty, P.V.J. \& Naudé, R.T., 1970. The accuracy of measurement of individual skeletal muscle fibres separated by a rapid technique. Lab. Pract. 19, 161-163.

Hood, D.E \& Riordan, E.B, 1973. Discolouration in pre-packaged beef: Measurement by reflectance spectrophotometry and shopper discrimination. Int. J. Food Sci. Tech. 8, 333-343.

Hwang, I.H., Park, B.Y., Cho, S.H. \& Lee, J.M., 2004. Effects of muscle shortening and proteolysis on Warner-Bratzler shear force in beef longissimus and semitendinosus. Meat Sci. 68, 497-505.

Hogg, B.W., Mercer, G.J.K., Mortimer, B.J., Kirton, A.H. \& Duganzich, D.M., 1992. Carcass and meat quality attributes of commercial goats in New Zealand. Small Rumin. Res. 8, 243-256.

Irie, M., Izumo, A. \& Mohri, S., 1996. Rapid method for determining water holding capacity in meat using video image analysis and simple formulae. Meat Sci. 42, 95-102.

Johnson, D.D., McGowan, C.H., Nurse, G. \& Anous, M.R., 1995 Breed type and sex effects on carcass traits, composition and tenderness of young goats. Small Rumin. Res. 17, 57-63.

Kadim, I.T., Mahgoub, O., Al-Ajmi, D.S., Al-Maqbaly, R.S., Al-Saqri, N.M. \& Ritchie, A., 2003. An evaluation of the growth, carcass and meat quality characteristics of Omani goat breeds. Meat Sci. 66, 203-210.

Kadim, I.T., Mahgoub, O., Al-Kindi, A., Al-Marzooqi, W. \& Al-Saqri, N.M., 2006. Effects of transportation at high ambient temperatures on physiological responses, carcass and meat quality characteristics of three breeds of Omani goats. Meat Sci. 73, 626-634.

Kadim, I.T, Mahgoub, O. \& Khalaf, S., 2014. Effects of the transportation during hot season and electrical stimulation on meat quality characteristics of goat Longissimus dorsi muscle. Small Rumin. Res. 121, 120-124.

Kannan, G., Kouakou, B. \& Gelaye, S., 2001. Colour changes reflecting myoglobin and lipid oxidation in chevon cuts during display. Small Rumin. Res. 42, 67-75.

Kannan, G., Lee, J. \& Kouakou, B., 2014. Chevon quality enhancement: Trends in pre-and post-slaughter techniques. Small Rumin. Res. 121, 80-88.

King, D.A., Voges, K.L., Hale, D.S., Waldron, D.F, Taylor, C.A. \& Savell, J.W., 2004. High voltage electrical stimulation enhances muscle tenderness, increases aging response, and improves muscle color from cabrito carcasses. Meat Sci. 68, 529-535.

Kouakou, B., Gelaye, S., Kannan, G., Pringle, T.D. \& Amoah, E.A., 2005. Blood metabolites, meat quality and muscle calpain-calpastatin activities in goats treated with low doses of recombinant bovine somatotropin. Small Rumin. Res. 57, 203-212.

Krzywicki, K., 1979. Assessment of relative content of myoglobin, oxymyoglobin and metmyoglobin at the surface of beef. Meat Sci. 3, 1-10.

Lawrie, R.A. \& Ledward, D.A., 2006. Lawrie's meat science. Woodhead, Cambridge, England. 99 pp.

Lee, J.H., Kouakou, B. \& Kannan, G., 2008. Chemical composition and quality characteristics of chevon from goats fed three different post-weaning diets. Small Rumin. Res.75, 177-184.

Locker, R.H. \& Hagyard, C.J., 1963. A cold shortening effect in beef muscles. J. Sci. Food Agric. 14, 787-793.

Malan, S.W., 2000. The improved Boer goat. Small Rumin. Res. 36, 165-170.

Marichal, A., Castro, N., Capote, J. Zamorano, M.J. \& Argüello, A., 2003. Effects of live weight at slaughter (6, 10 and 25 $\mathrm{kg}$ ) on kid carcass and meat quality. Livest. Prod. Sci. 83, 247-256.

Madruga, M.S., Torres, T.S., Carvalho, F.F., Queiroga, R.C., Narain, N., Garrutti D., Souza Neto, M.A., Mattos, C.W. \& Costa R.G., 2008. Meat quality of Moxoto and Caninde goats as affected by two levels of feeding. Meat Sci. 80, 1019-1023

McPhee, C. \& Trout, G., 1995. The effects of selection for lean growth and the halothane allele on carcass and meat quality of pigs transported long and short distances to slaughter. Livest. Prod. Sci. 42, 55-62.

Nagaraj, N.S., Anilakumar, K.R. \& Santhanam, K., 2002. Changes in the calpain-calpastatin and cathepsin (B, B+L, H and D) during postmortem storage of goat muscles J. Food Biochem. (26) 75-89.

Pratiwi, N.M.W., Murray, P. \& Taylor, D., 2007. Feral goats in Australia: A study on the quality and nutritive value of their meat. Meat Sci. 75, 168-177.

Safari, J., Mushi, D.E., Mtenga, L.A., Kifaro, G.C. \& Eik, L.O., 2011. Growth, carcass and meat quality characteristics of Small East African goats fed straw based diets. Livest. Sci. 135, 168-176.

Schönfeldt, H.C., Naudè, R.T., Bok, W., Van Heerden, S.M., Sowden, L. \& Boshoff, E., 1993. Cooking- and juicinessrelated quality characteristics of goat and sheep meat. Meat Sci. 34, 381-394. 
Shackelford, S.D., Morgan, J.B., Cross, H.R. \& Savell, J.W., 1991. Identification of threshold levels for Warner Bratzler shear press in beef top loin steaks. J. Muscle Foods 2, 289-296.

Simela, L., Ndlovu, L.R. \& Sibanda, L.M., 1999. Carcass characteristics of the marketed Matabele goat from southwestern Zimbabwe. Small Rumin. Res. 32, 173-179.

Simela, L., Webb, E.C. \& Frylinck, L., 2004. Effect of sex, age, and pre-slaughter conditioning on pH, temperature, tenderness and colour of indigenous South African goats. S. Afr. J. Anim. Sci. 34, 208-211.

Simela, L., Webb, E.C. \& Bosman, M.J.C., 2011. Live animal and carcass characteristics of South African indigenous goats. S. Afr. J. Anim. Sci.41, 1-15.

SPSS, 2015. IBM SPSS Statistics for windows (version 23.0). IBM Corp., Armonk, New York, USA.

Strydom, P.E., Frylinck, L. \& Smith, M.F., 2005. Should electrical stimulation be applied when cold shortening is not a risk? Meat Sci. 70, 733-742.

Tarrant, P.V. \& Sherington, J., 1980. An investigation of ultimate $\mathrm{pH}$ in the muscles of commercial beef carcasses. Meat Sci. 4, 287-297.

Tshabalala, P.A., Strydom, P.E., Webb, E.C. \& De Kock, H.L., 2003. Meat quality of designated South African indigenous goat and sheep breeds. Meat Sci. 65, 563-570.

Van Niekerk, W. \& Casey, N., 1988. The Boer goat. II. Growth, nutrient requirements, carcass and meat quality. Small Rumin. Res.1, 355-368.

Visser, C., Hefer, C.A., Van Marle-Köster, E. \& Kotze, A., 2004. Genetic variation of three commercial and three indigenous goat populations in South Africa. S. Afr. J. Anim. Sci. 34, 24-27.

Warmington, B.G. \& Kirton, A.H., 1990. Genetic and non-genetic influences on growth and carcass traits of goats. Small Rumin. Res. 3, 147-165.

Webb, E.C., Casey, N.H. \& Simela, L., 2005. Goat meat quality. Small Rumin. Res. 60, 153-166. 